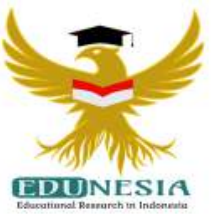

\title{
Analisis Hambatan Pembelajaran Biologi Materi Jaringan Tumbuhan Dalam Pelaksanaan Kurikulum 2013 Di SMA
}

\author{
Evi Susilawati' ${ }^{1}$ Khausar2; Rufa Hera ${ }^{3}$ \\ 1,3Pendidikan Biologi, STKIP Bina Bangsa Meulaboh, Indonesia \\ ${ }_{2}^{2}$ Pendidikan Guru Sekolah Dasar, STKIP Bina Bangsa Meulaboh, Indonesia \\ ${ }^{2}$ Corresponding Email: saraja970@gmail.com, Phone Number : $0823 x x x x x x x x x$
}

\section{Article History: \\ Received: Juni 30, 2020 \\ Revised: Juli 08, 2020 \\ Accepted: Agust 06, 2020 \\ Published: Nov 01, 2020}

\section{Keywords:}

Difficulty of Learning Biology, Implementation of curriculum 2013,

Kata Kunci:

Implementasi Kurikulum 2013, Kesulitan Pembelajaran Biologi.

How to cite:

Susilawati,E., Khausar., \& Hera, R. (2020). Analisis Hambatan Pembelajaran Biologi Materi Jaringan Tumbuhan Dalam Pelaksanaan Kurikulum 2013 Di SMA. Edunesia : Jurnal Ilmiah Pendidikan, 1 (3): 1-8

This is an open access article under the $C C$-BY-NC-ND license

\section{(c) $(1)$}

Abstract: This study aims to determine: 1) barriers to learning biology of plant tissue material in the implementation of 2013 class XI curriculum at SMA Negeri 1 Meureubo; 2) factors inhibiting the learning of plant tissue biology in the implementation of the 2013 XI class curriculum at SMA Negeri 1 Meureubo. This research uses qualitative. From the results of the study, there are obstacles faced by class XI teachers of SMA Negeri 1 Meureubo in the learning process of plant tissue biology in the implementation of the 2013 curriculum, which are the availability of books and supporting infrastructure which are inadequate, too short training, limited use of media, and assessment is so difficult and requires a lot of time.

Abstrak: Penelitian ini bertujuan untuk mengetahui: 1) hambatan pembelajaran biologi materi jaringan tumbuhan dalam pelaksanaan kurikulum 2013 kelas XI SMA Negeri 1 Meureubo; 2) faktor-faktor hambatan pembelajaran biologi materi jaringan tumbuhan dalam pelaksanaan kurikulum 2013 kelas XI SMA Negeri 1 Meureubo. Penelitian ini menggunakan kualitatif. Dari hasil penelitian maka terdapat hambatanhambatan yang dihadapi guru kelas XI SMA Negeri 1 Meureubo dalam proses pembelajaran biologi materi jaringan tumbuhan pada pelaksanaan Kurikulum 2013 adalah ketersediaan buku dan sarana prasarana pendukung yang kurang memadai, pelatihan yang terlalu singkat, penggunaan media yang terbatas, serta penilaian yang begitu sulit serta membutuhkan waktu yang banyak. 


\section{A. Pendahuluan}

Pendidikan merupakan hal yang sangat penting dan tak bisa lepas dari kehidupan manusia. Di dalam Undang-Undang Nomor 20 Tahun 2003 Tentang Sistem Pendidikan Nasional pasal 1 ayat 1 menyatakan bahwa pendidikan adalah suatu usaha sadar dan terencana untuk mewujudkan suasana belajar dan proses pembelajaran agar peserta didik secara aktif mengembangkan potensi dirinya untuk memiliki kekuatan spiritual keagamaan, pengendalian diri, kepribadian, kecerdasan, akhlak mulia, serta keterampilan yang diperlukan dirinya, masyarakat, bangsa dan negara. (Novrinda dkk, 2017)

Guru dalam mewujudkan suasana belajar dan proses pembelajaran yang baik untuk mendapatkan nilai hasil belajar yang memuaskan tidak serta merta mudah, oleh karena itu pembelajaran di sekolah harus direncanakan dengan baik sehingga pembelajaran dapat bermanfaat (Widiyanti \& Hadi, 2020). Pembelajaran Biologi dapat dilaksanakan di ruang kelas, laboratorium melalui kegiatan praktikum, atau secara langsung di alam melalui studi lapangan. Proses pembelajaran tersebut dapat berhasil karena adanya interaksi antara guru dan siswa. (Kusumawati, 2016)

Upaya guru untuk menciptakan suasana pembelajaran kondusif dan dapat menuntun siswa bersifat aktif dan kreatif. Suasana pembelajaran seperti ini, akan memberi harapan bagi tercapainya hasil belajar siswa secara maksimal, dalam arti tercapainya sejumlah kemampuan daan keterampilan proses. Dengan demikian diharapkan pula siswa mampu memecah masalah yang ada dilingkungan belajar (Khausar, 2014)

Keberhasilan proses belajar dipengaruhi oleh banyak faktor, seperti faktor sekolah meliputi kurikulum, metode mengajar, relasi antara siswa dengan guru maupun siswa dengan siswa, dan alat pelajaran (Ariska \& Rahman, 2020). Guru sebagai salah satu penanggung jawab pembelajaran di sekolah memegang peranan penting dalam mengelola faktor yang mempengaruhi belajar siswa (Priyayi, 2016). Sesuai dengan Permendikbud Nomor 65 tahun 2013 berkaitan dengan standar proses, guru perlu merancang pembelajaran yang membuat siswa lebih aktif untuk mencari tahu. Paradigma yang sumber belajar, diubah menjadi belajar berbasis aneka sumber belajar. Proses belajar diharapkan dapat mengajak siswa untuk mengembangkan kemampuannya secara holistik, baik pada ranah sikap, pengetahuan maupun keterampilan. (Priyayi, 2016)

Adanya kelengkapan sarana dan prasarana serta pengaruh lingkungan sekolah sangat menunjang pembelajaran, terutama pembelajaran biologi yang sering menggunakan laboratorium maupun lingkungan sekitar sekolah untuk kegiatan pembelajaran. Oleh karena itu, apabila pemahaman pendidik tentang Kurikulum 2013 dan kelengkapan sarana dan prasarana sekolah masih kurang memadai akan menjadi hambatan dalam terlaksananya Kurikulum 2013. Ternyata penerapan Kurikulum 2013 ini tidak seperti yang diharapkan.

Berdasarkan hasil wawancara yang dilakukan pada bulan Februari 2019 dengan para pendidik biologi di SMA Negeri 1 Meureubo masih ada kesulitan atau hambatan yang di hadapi oleh para pendidik biologi dalam pembelajaran biologi yang sesuai dengan tuntutan Kurikulum 2013, diantaranya yaitu sulit menentukan model pembelajaran yang sesuai dengan KD (Kompetensi Dasar), kesulitan dalam penilaian afektif dengan jumlah peserta didik yang sangat banyak, dan kesulitan menentukan penggunaan media pembelajaran untuk materi yang tidak di praktikumkan. Beberapa pendidik lain juga menyatakan bahwa peserta didik masih terbiasa dengan pembelajaran menggunakan kurikulum yang lama sehingga pendidik belum sepenuhnya bisa menerapkan Kurikum 2013. 
Hasil penelitian yang dilakukan oleh Aeni dkk, (2016) ada beberapa aspek yang menunjukkan kesulitan pendidik biologi dalam proses perencanaan, yaitu pendidik masih sulit membuat RPP yang sesuai dengan Kurikulum 2013, pendidik sulit menentukan metode pembelajaran yang sesuai dengan materi, dan pendidik kesulitan dalam menggunakan sumber belajar. Hasil penelitian Mayang (2015) menyebutkan bahwa, sebagian besar pendidik biologi belum memahami betul tentang pendekatan ilmiah (scientfic approach) pada kurikulum 2013.

\section{B. Metode}

Penelitian ini menggunakan pendekatan kualitatif, yang berusaha memahami dan menafsirkan makna suatu peristiwa, interaksi dan tingkah-laku manusia dalam situasi tertentu menurut perspektif peneliti sendiri.

Jenis Penelitian ini bersifat deskriptif (descriptive research) atau suatu penelitian yang ditujukan untuk menggambarkan fenomena-fenomena yang ada yang berlangsung pada saat ini atau saat yang lampau. Adapun tujuan dari penelitian ini adalah untuk mengungkapkan kejadian atau fakta, keadaan, fenomena, variabel dan keadaan hasil indentifikasi hambatan pembelajaran biologi materi jaringan tumbuhan dalam pelaksanaan kurikulum 2013 kelas XI MIAI SMA Negeri 1 Meureubo.

Instrumen yang digunakan untuk mengumpulkan data dalam penelitian ini terdiri dari lembar observasi, lembar wawancara dan lembar validasi.

\section{Hasil dan Pembahasan}

Tabel 1.

Hasil Validasi

\begin{tabular}{lccccc}
\hline Validasi & Skor V & Skor V & Rata-Rata & Saran $\mathbf{V}_{\mathbf{1}}$ & Saran $\mathbf{V}_{\mathbf{2}}$ \\
\hline Wawancara & 4 & 3 & 4 & - & - \\
\hline Observasi Guru & 4 & 4 & 4 & - & $\begin{array}{l}\text { Keluwesan guru } \\
\text { dalam menerapkan } \\
\text { k-13 juga } \\
\text { dicantumkan }\end{array}$ \\
\hline $\begin{array}{l}\text { Observasi } \\
\text { Siswa }\end{array}$ & 4 & 3 & 4 & - & - \\
\hline Angket & 4 & 3 & 4 & - & - \\
\hline Keterngan & & & & & \\
\hline
\end{tabular}

Keterangan :

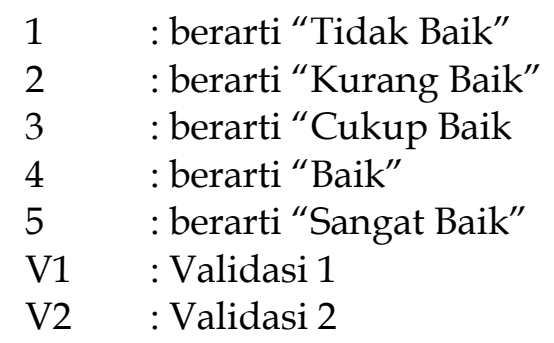

Validasi wawancara skor validasi 1 adalah 4 dan tidak mempunyai saran, validasi 2 adalah 3 dan tidak mempunyai saran. Validasi pada skor observasi guru skor validasi 1 adalah 4 dan tidak mempunyai saran, validasi 2 adalah 4 dan mempunyai saran 
keluwesan guru dalam menerapkan k-13 juga dicantumkan. Validasi pada skor observasi siswa skor validasi 1 adalah 4 dan tidak mempunyai saran, validasi 2 adalah 3 dan tidak mempunyai saran. Validasi pada skor angket skor validasi 1 adalah 4 dan tidak mempunyai saran, validasi 2 adalah 3 dan tidak mempunyai saran. Dari uraian tersebut maka hasil validasi dinyatakan valid.

Tabel 2.

Observasi Guru

\begin{tabular}{|c|c|c|c|c|c|c|}
\hline \multirow{2}{*}{ No } & \multirow{2}{*}{ Kegiatan } & \multicolumn{5}{|c|}{ Kategori Penelitian } \\
\hline & & 1 & 2 & 3 & 4 & 5 \\
\hline 1 & Tingkat guru memberikan materi & & & $\sqrt{ }$ & & \\
\hline 2 & $\begin{array}{l}\text { Tingkat guru dalam merespon } \\
\text { pertanyaan-pertanyaan yang muncul saat } \\
\text { proses belajar mengajar }\end{array}$ & & & $\sqrt{ }$ & & \\
\hline 3 & $\begin{array}{lcc}\text { Tingkat guru dalam } & \text { menjawab } \\
\text { pertanyaan siswa }\end{array}$ & & & $\sqrt{1}$ & & \\
\hline 4 & $\begin{array}{l}\text { Kedalaman wawasan guru terhadap } \\
\text { materi yang terkait }\end{array}$ & & & & $\sqrt{ }$ & \\
\hline 5 & $\begin{array}{l}\text { Kemampuan guru dalam menguasai } \\
\text { kelas }\end{array}$ & & & & $\sqrt{ }$ & \\
\hline
\end{tabular}

Keterangan :

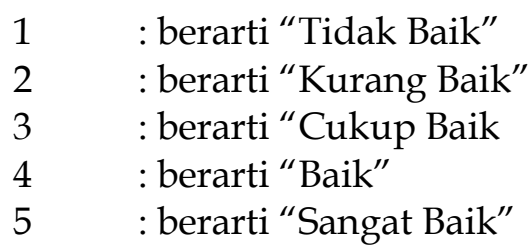

Tabel 3.

Observasi Siswa

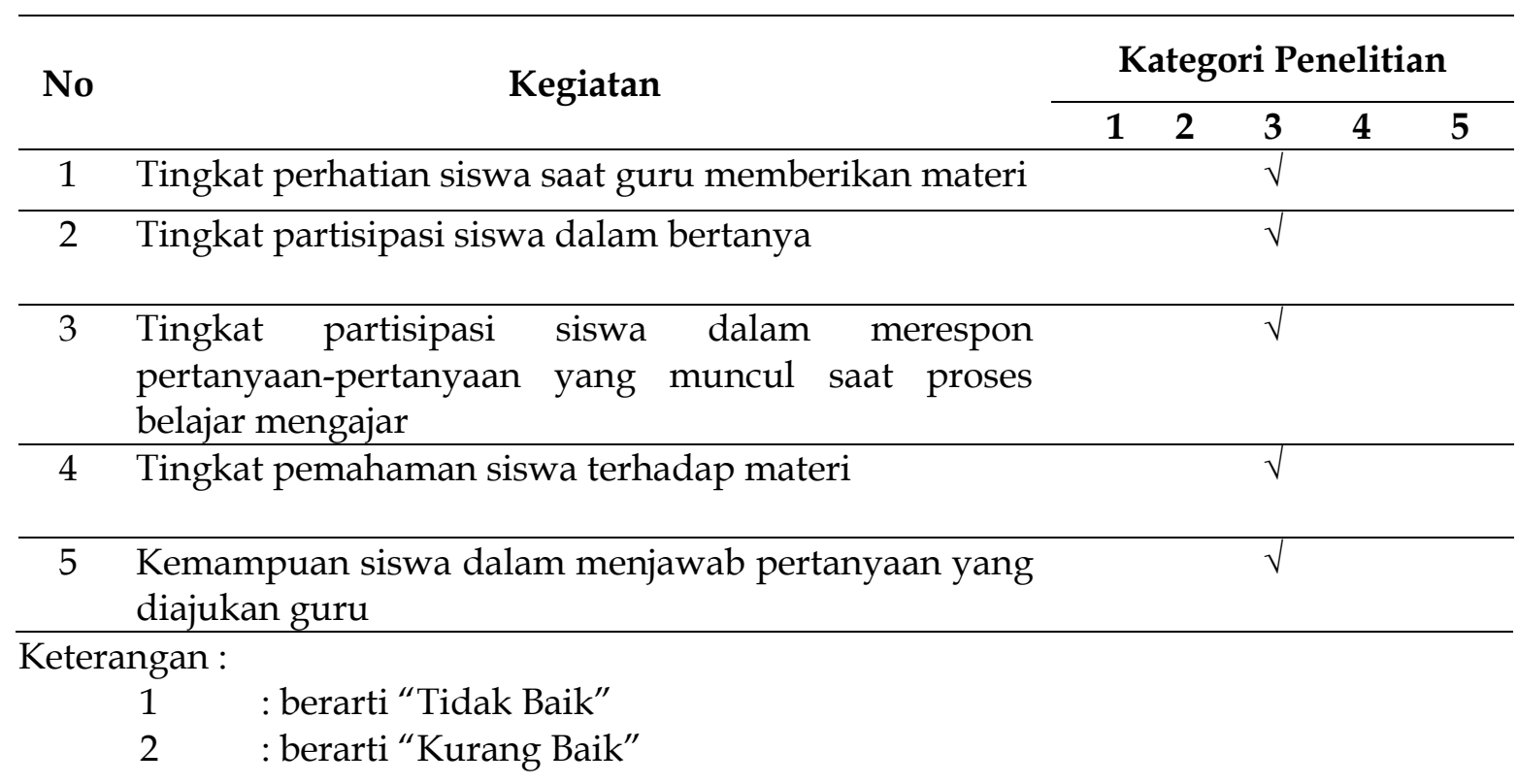




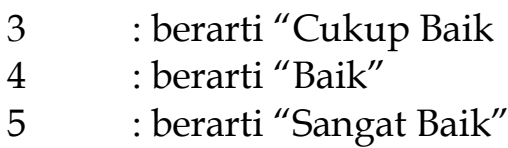

Tabel 4.

Angket Konsep Kurikulum 2013

\begin{tabular}{clccc}
\hline No & \multicolumn{1}{c}{ Penyatan } & Persentase & Kategori \\
\hline 1 & $\begin{array}{l}\text { Saya siap dan setuju dengan perubahan kurikulum dari } \\
\text { KTSP ke Kurikulum 2013 }\end{array}$ & $75 \%$ & Baik \\
\hline 2 & $\begin{array}{l}\text { Kurikulum 2013 disusun dengan mengacu pada standar isi } \\
\text { (SI) dan standar Kompetensi Lulusan (SKL) tidak } \\
\text { berpedoman pada panduan yang disusun oleh Badan } \\
\text { Standar Nasional Pendidikan (BSNP). }\end{array}$ & $70 \%$ & Baik \\
\hline 3 & $\begin{array}{l}\text { Saya setuju dengan diadakannya pelatihan implementasi } \\
\text { kurikulum 2013 }\end{array}$ & $80 \%$ & $\begin{array}{c}\text { Sangat } \\
\text { Baik }\end{array}$ \\
\hline 4 & $\begin{array}{l}\text { Materi pembelajaran dalam Kurikulum 2013 disajikan } \\
\text { terpadu }\end{array}$ & $75 \%$ & Baik \\
\hline 5 & $\begin{array}{l}\text { Siswa tidak dibiasakan menyusun teks yang sistematis, } \\
\text { logis, dan efektif }\end{array}$ & $75 \%$ & Baik \\
\hline & \multicolumn{1}{c}{ Rata-Rata } & $75 \%$ & Baik \\
\hline
\end{tabular}

Tabel 5.

Angket Konsep Silabus

\begin{tabular}{clcc}
\hline No & \multicolumn{1}{c}{ Penyataan } & Persentase & Kategori \\
\hline 1 & $\begin{array}{l}\text { Silabus Kurikulum 2013 dikembangkan sendiri oleh } \\
\text { sekolah/ MGMP sesuai dengan karakteristik dan potensi } \\
\text { siswa }\end{array}$ & $85 \%$ & $\begin{array}{c}\text { Sangat } \\
\text { Baik }\end{array}$ \\
\hline 2 & $\begin{array}{l}\text { Silabus pembelajaran Kurikulum 2013 tidak disusun } \\
\text { berdasarkan Standar Isi (SI) dan Standar Kompetensi } \\
\text { Lulusan (SKL) }\end{array}$ & $80 \%$ & Baik \\
\hline 3 & Silabus pembelajaran tidak memuat Kompetensi dasar & $70 \%$ & Baik \\
\hline & \multicolumn{1}{c}{ Rata-Rata } & $78 \%$ & Baik \\
\hline
\end{tabular}

Tabel 6.

Angket RPP Kurikulum 2013

\begin{tabular}{clcc}
\hline No & \multicolumn{1}{c}{ Penyataan } & Persentase & Kategori \\
\hline 1 & $\begin{array}{l}\text { RPP disusun berdasarkan ranah Kompetensi Inti (KI) } \\
\text { yaitu sikap spiritual (KI1), Sikap sosial (KI2), Pengetahuan } \\
\text { (KI3), dan Keterampilan (KI4) }\end{array}$ & $85 \%$ & Sangat Baik \\
\hline 2 & $\begin{array}{l}\text { Dalam RPP Kurikulum 2013 berisi model pembelajaran } \\
\text { yang mampu mengiring siswa untuk menemukan konsep }\end{array}$ & $95 \%$ & Sangat Baik \\
\hline
\end{tabular}




\begin{tabular}{|c|c|c|c|}
\hline No & Penyataan & Persentase & Kategori \\
\hline \multicolumn{4}{|c|}{ yang akan dipelajari } \\
\hline 3 & $\begin{array}{l}\text { RPP yang disusun berisikan langkah-langkah yang mana } \\
\text { agar guru bisa lebih aktif dalam pelaksanaan } \\
\text { pembelajaran }\end{array}$ & & Sangat Baik \\
\hline 4 & $\begin{array}{l}\text { Penyusunan Rencana Pelaksanaan Pembelajaran (RPP) } \\
\text { mencantumkan pendekatan saintifik melalui mengamati, } \\
\text { menanya, mencoba, menalar dan menyaji }\end{array}$ & $85 \%$ & Sangat Baik \\
\hline 5 & $\begin{array}{l}\text { Dalam Kurikulum } 2013 \text { RPP disusun sesuai dengan } \\
\text { alokasi waktu yang ditetapkan }\end{array}$ & $80 \%$ & Sangat Baik \\
\hline \multirow[t]{2}{*}{6} & Dalam RPP setiap pertemuan tidak ada penilaian & $99 \%$ & Sangat Baik \\
\hline & Rata-Rata & $89,83 \%$ & Sangat Baik \\
\hline
\end{tabular}

Temuan penelitian yang dimaksud disini yaitu mengungkapkan data yang diperoleh secara langsung dari hasil penelitian lapangan yang sesuai dengan rumusan masalah yang ada dalam pembahasan skripsi ini.

Dari tabel persentase pemahaman guru tentang konsep kurikulum 2013 rata-rata persentasenya sebesar 75\% dengan kriteria baik, hal ini dapat dilihat bahwa guru yang mengajar biologi dengan menggunakan kurikulum 2013 sudah sangat baik dalam memahami kurikulum 2013. Pernyataan tertinggi terdapat pada pernyataan ke empat, yaitu dengan rata-rata persentase semua guru $80 \%$. Hal ini karena guru telah mengikuti pelatihan Implementasi kurikulum 2013, Musyawarah Guru Mata Pelajaran (MGMP) dan workshop yang diadakan oleh pihak sekolah sehingga mampu menambah pengetahuan serta pemahaman guru tentang kurikulum 2013. Sedangkan persentase rata-rata pernyataan terendah yaitu $70 \%$, terdapat pada pernyataan dua dikarenakan ada satu orang guru yang tidak mengikuti pelatihan kurikulum 2013.

Sebagaimana guru tersebut pada saat diadakannya pelitihan kurikulum 2013 sedang mengambil cuti. Namun dalam pelaksanaan kurikulum 2013 guru haruslah siap dan mampu mengembangkan kurikulum yang digunakan agar sesuai dengan keadaan disekolah.

menyatakan Strategi yang digunakan oleh guru dalam menghadapi penerapan Kurikulum 2013 yakni dengan guru bertanya kepada rekan sesama guru terutama dilakukan dalam kegiatan MGMP dengan guru lain yang dianggap mampu memberikan informasi yang dibutuhkan, mencari buku referensi yang digunakan sebagai sumber kegiatan pembelajaran, serta mencari informasi dengan browsing dari internet sebagai salah satu bentuk usaha dalam menambah pengetahuan dengan memanfaatkan kemajuan teknologi. Strategi yang dilakukan guru merupakan salah satu bentuk belajar mandiri guna menunjang penerapan Kurikulum 2013 yang ada di sekolah. Selain memahami

Rata-rata persentase bahasa sebanyak $87.5 \%$ dengan kriteria valid. konsep kurikulum 2013, guru juga harus memahami cara penyusunan silabus pembelajaran. Sebagaimana pemahaman guru dalam menyusun silabus pembelajaran kurikulum 2013 di SMA Negeri 1 Meureubo sudah baik dengan persentase rata-rata 75\%.

Berdasarkan tabel indikator pemahaman guru dalam menyusun silabus pembelajaran di atas, diperoleh persentase pernyataan tertinggi pada nomor 1 yaitu 85\%, hal ini menunjukkan bahwa pemahaman guru dalam menyusun silabus pembelajaran kurikulum 2013 sangatlah baik. Karena selain pemahaman yang didapatkan pada saat 
implementasi kurikulum 2013, guru juga telah mengembangkan sendiri silabus pembelajaran sesuai dengan karakteristik dan potensi siswa. Sedangkan persentase pernyataan terendah pada nomor 3 yaitu 70\%, hal ini dikarenakan terdapat satu orang guru berinisial YL yang mana menjawab "selalu" dengan arti guru tersebut tidak pernah memuat kompetensi dasar pada saat penyusunan silabus pembelajaran.

Namun pada dasarnya silabus pembelajaran haruslah memuat kompetensi dasar, karena kompetensi dasar dikembangkan berdasarkan pada prinsip akumulatif, saling memperkuat (reinforced) dan memperkaya (enriched) antar mata pelajaran dan jenjang pendidikan (organisasi horizontal dan vertikal) (Kartimi, Chandra dan Rosdiana, 2014).

penyajian materi tersusun secara sistematis dengan materi yang Kompetensi dasar juga dirumuskan untuk mencapai kompetensi inti. Rumusan kompetensi dasar dikembangkan dengan memperhatikan karakteristik peserta didik, kemampuan awal, serta ciri dari suatu mata pelajaran. Kompetensi dasar dibagi menjadi empat kelompok sesuai dengan pengelompokkan kompetensi inti yaitu kelompok pertama kompetensi dasar sikap spiritual dalam rangka menjabarkan KI-1. kelompok kedua kelompok kompetensi dasar sikap sosial dalam rangka menjabarkan KI-2. Kelompok ketiga kelompok kompetensi dasar pengetahuan dalam rangka menjabarkan KI-3. Kelompok ke empat kelompok kompetensi dasar keterampilan dalam rangka menjabarkan KI-4 (Permendikbud, 2013). Kemudian pemahaman guru dalam menyusun rencana pelaksanaan pembelajaran Kurikulum 2013 di SMA Negeri 1 Meureubo sudah baik. Hal ini dibuktikan dengan rata-rata persentase yang diperoleh yaitu $78 \%$.

Dari tabel persentase rata-rata pernyataan tertinggi yaitu $99 \%$ terdapat pada pernyataan nomor 6 yang mana guru sangat memahami bahwa dalam penyusunan RPP setiap pertemuan harus ada penilaian. Karena dalam kurikulum 2013 selalu ada penilaian yakni dengan penilaian otentik, baik ranah kognitif, afektif dan psikomotor. Dimana permendikbud (2013) telah menyatakan bahwa untuk ranah kognitif siswa haruslah memiliki pengetahuan faktual, konseptual, dan prosedural dalam ilmu pengetahuan, teknologi, seni, dan budaya dengan wawasan kemanusiaan, kebangsaan, kenegaraan, dan peradaban terkait fenomena dan kejadian yang tampak oleh mata. Kemudian ranah afektif siswa haruslah memiliki perilaku yang mencerminkan sikap orang beriman, berakhlak mulia, berilmu, percaya diri, dan bertanggung jawab dalam berinteraksi secara efektif denganlingkungan sosial dan alam dalam jangkauan pergaulan dan keberadaannya. Sedangkan ranah psikomotor siswa haruslah memiliki kemampuan piker, tindak yang efektif, kreatif dalam ranah abstrak dan konkret sesuai dengan yang dipelajari disekolah serta sumber lain sejenis.

Kemudian pernyataan rata-rata terendah terdapat pada nomor 5 dengan persentase $80 \%$, hal ini dikarenakan 4 orang guru menjawab sering dalam arti kata guru masih belum sepenuhnya menyusun RPP sesuai dengan alokasi waktu yang ada. Akan tetapi dalam penyusunan RPP guru harus selalu menyesuaikan dengan alokasi waktu yang ditetapkan. Dimana alokasi waktu harus sesuai dengan jumlah jam pelajaran dalam struktur kurikulum untuk satu semester atau satu tahun (Permendikbud, 2013:5). Penyusunan RPP dengan alokasi waktu yang cukup memungkinkan guru dan siswa untuk melakukan langkah-langkah pembelajaran yang konseptual antara lain riset, menganalisis pustaka, eksplorasi dan eksperimen (Subkhan, 2015). Selanjutnya guru juga harus memahami bagaimana cara pelaksanaan pembelajaran kurikulum 2013. 
Sebagaimana hasil dari analisis data jawaban responden yang di peroleh menunjukkan bahwa pemahaman guru dalam melaksanakan pembelajaran kurikulum 2013 sangatlah baik, dengan persentase rata-rata yang diperoleh responden yaitu 83,33\%.

\section{Kesimpulan}

Berdasarkan hasil penelitian terdapat hambatan-hambatan yang dihadapi guru kelas XI SMA Negeri 1 Meureubo dalam proses pembelajaran biologi materi jaringan tumbuhan pada pelaksanaan Kurikulum 2013 adalah ketersediaan buku dan sarana prasarana pendukung yang kurang memadai, pelatihan yang terlalu singkat, penggunaan media yang terbatas, serta penilaian yang begitu sulit serta membutuhkan waktu yang banyak.

\section{Daftar Pustaka}

Aeni, U., \& Chandra, E. (2016). Identifikasi Kesulitan Guru Biologi Dalam Melaksanakan Pembelajaran Kurikulum 2013 Di SMA Negeri 1 Susukan. Scientiae Educatia: Jurnal Pendidikan Sains, 5(2), 167-174.

Ariska, A., \& Rahman, A. A. (2020). Analisis Letak Kesalahan Jawaban Siswa Dalam Menyelesaikan Soal Cerita SPLTV Dengan Menggunakan Pendekatan Scientific Berbasis Newman Di Kelas X SMA. Edunesia: Jurnal Ilmiah Pendidikan, 1(1), 1-9.

Khausar, K. (2018). Pengaruh Penerapan Metode Pembelajaran Guru Yang Bervariasi Terhadap Peningkatan Hasil Belajar Pada Siswa Kelas Xi Sma Negeri 1 Labuhanhaji Timur Aceh Selatan. Genta mulia: jurnal ilmiah pendidikan, 5(2).

Kusumawati, M, U. (2016). Identifikasi Kesulitan Belajar Materi Struktur Fungsi Jaringan Tumbuhan Pada Siswa SMA Negeri 3 Klaten Kelas XI, Jurnal Pendidikan Biologi, Vol $5, \mathrm{No} 7$

Novrinda, N., Kurniah, N., \& Yulidesni, Y. (2017). Peran Orangtua Dalam Pendidikan Anak Usia Dini Ditinjau Dari Latar Belakang Pendidikan. Jurnal Ilmiah Potensia, 2(1), 39-46.

Kemendikbud. (2016). Permendikbud No 020 tahun 2016 Tentang Standar Kompetensi Lulusan Pendidikan Dasar Dan Menengah. Jakarta:kemendikbud

Priyayi, D, S. (2016). Analisis Bahan Ajar Model Pembelajaran Alid (Accelerated Learning Included By Discovery) Pada Materi Jaringan Tumbuhan Kelas XI SMA N 7 Surakarta, Jurnal Pendidikan Sains, Volume 04 Nomor 01.

Susilo, A. (2013). Teori Belajar \& Pembelajaran di Sekolah Dasar, Jakarta: Kencana Prenadamedia Group.

Widiyanti, D., \& Hadi, K. (2020). Pengembangan Lembar Kerja Siswa (LKS) Bernuansa Quantum Teaching Untuk Meningkatkan Minat Dan Hasil Belajar Siswa Kelas IV Di Sekolah Dasar. Edunesia: Jurnal Ilmiah Pendidikan, 1(2), 26-34. 